SUPPORTING INFORMATION FOR:

"Phase Diagrams and Structural Characterization of Mixtures of Silicone

Surfactants + Silicone Oils + Water"

Maira Silva Ferreira ${ }^{\dagger 1}$; Harry Westfahl Jr' Watson Loh ${ }^{1}$

${ }^{1}$ Institute of Chemistry, University of Campinas (UNICAMP), P.O. Box 6154,

Campinas, SP, 13084-970, Brazil

${ }^{2}$ Brazilian Synchrotron Light Laboratory (LNLS), Brazilian Center for Research in

Energy and Materials (CNPEM), 13083-970, Campinas, Sao Paulo, Brazil

† Present address: Coordination of Science and Technology,

Federal University of Maranhão (UFMA), 65080-805, São Luís, Maranhão, Brazil. 


\section{SECTION A:}

Additional Information on Surfactant Characterization by ${ }^{13} \mathrm{C}$ and ${ }^{1} \mathrm{H}$ NMR

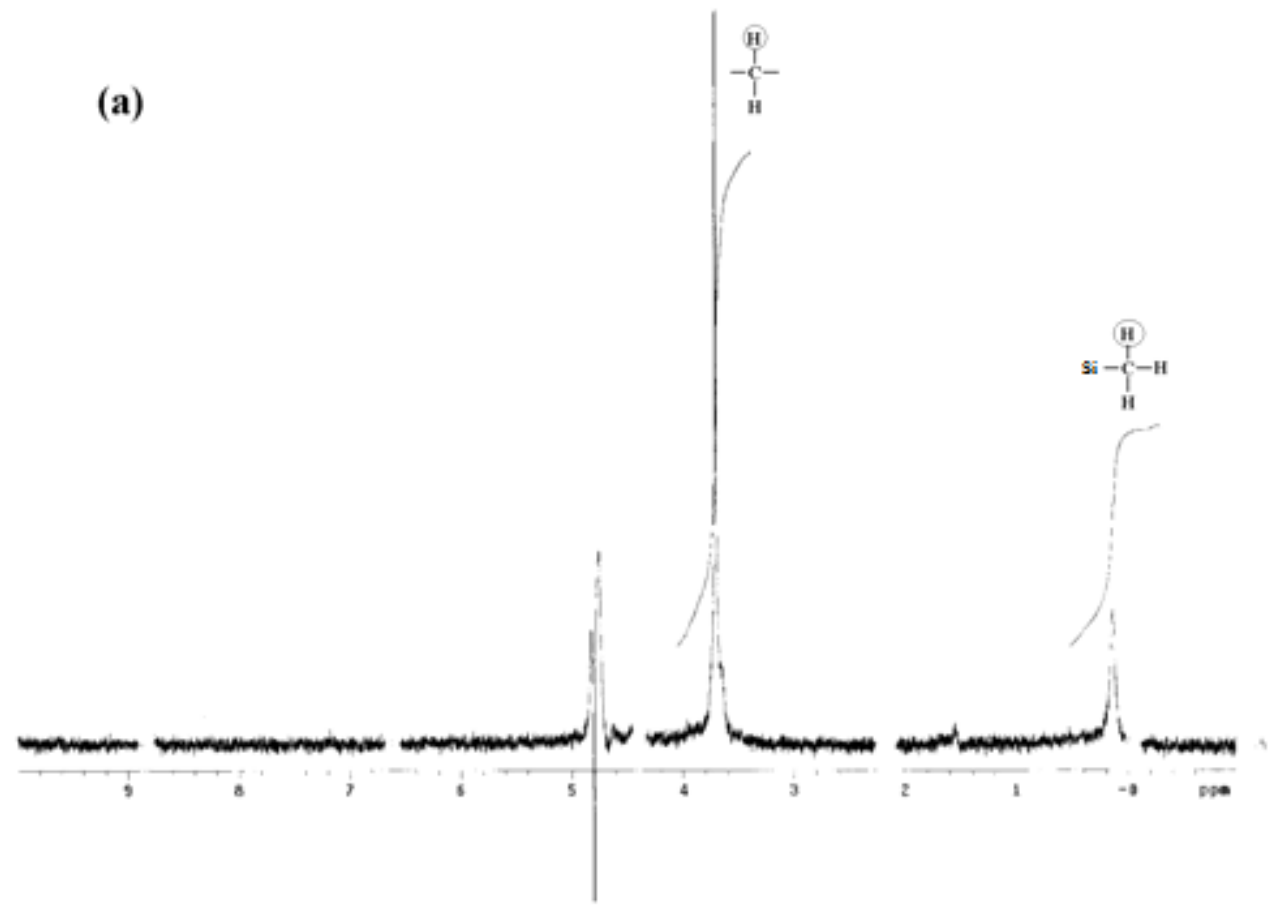

(b)

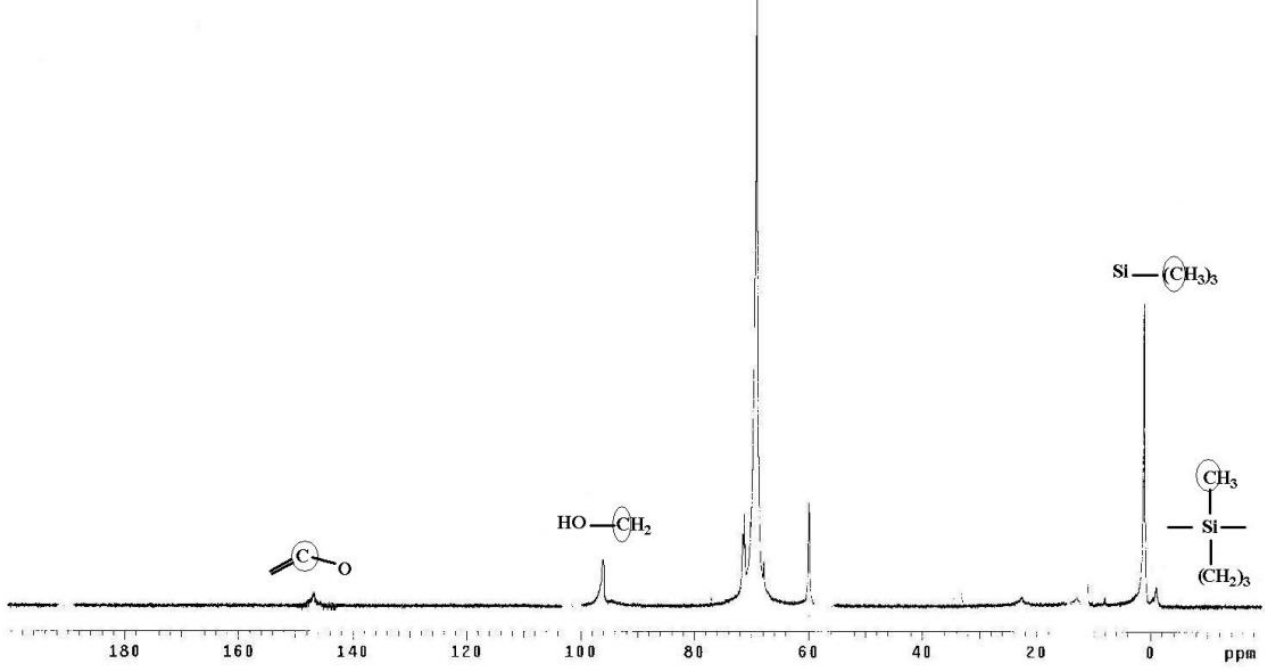

Figure S1.NMR spectra of surfactant $\mathrm{M}\left(\mathrm{D}^{\prime} \mathrm{E}_{7} \mathrm{OH}\right) \mathrm{M}$ in $\mathrm{D}_{2} \mathrm{O}$ : (a) ${ }^{1} \mathrm{H} N \mathrm{NR}$ spectra at $300 \mathrm{MHz}$ and (b) ${ }^{13} \mathrm{C}$ NMR spectra at $125 \mathrm{MHz}$. 
(a)

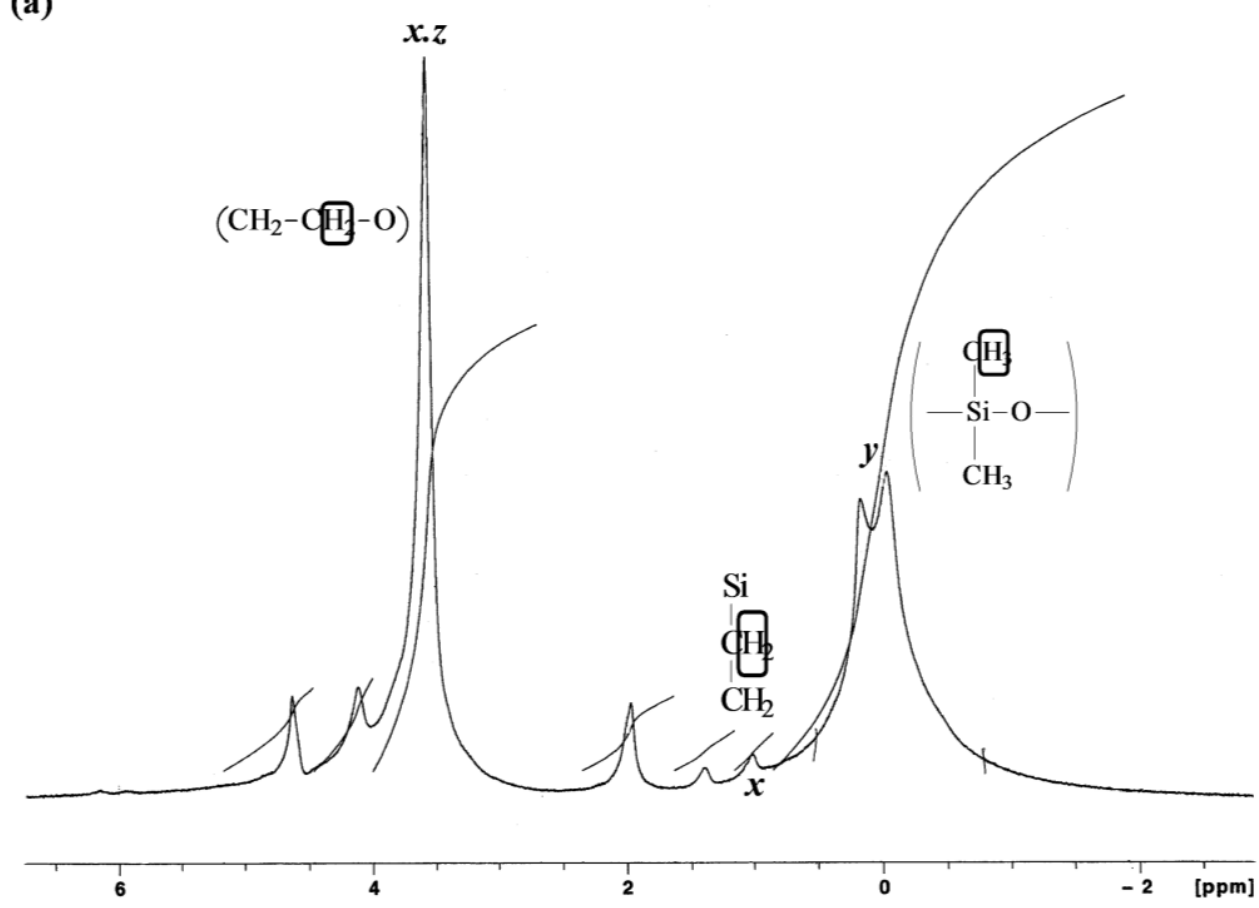

(b)

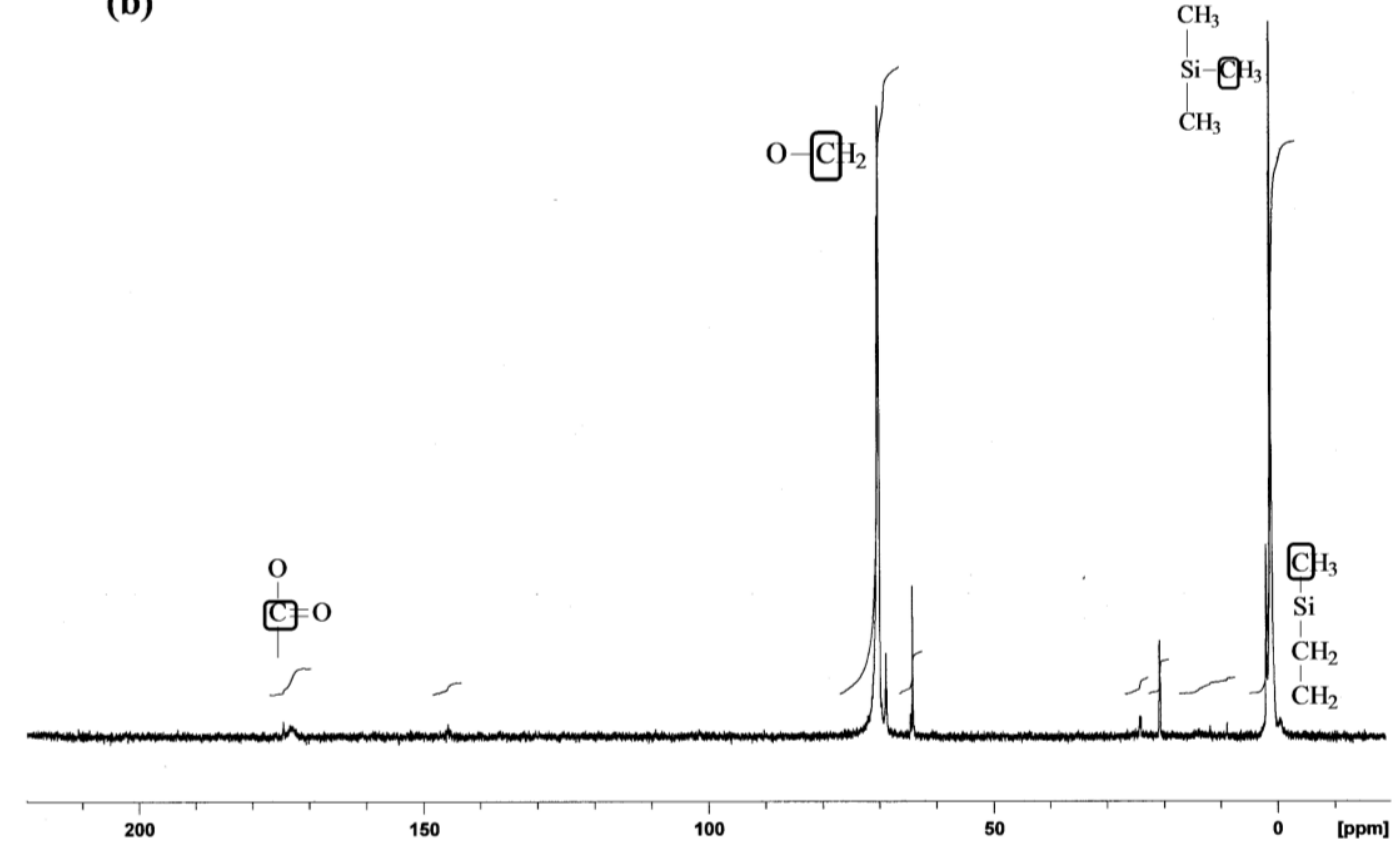

Figure S2.NMR spectra of surfactantMD ${ }_{18}\left(\mathrm{D}^{\prime}{ }_{3} \mathrm{E}_{18} \mathrm{OAc}\right) \mathrm{M}$ in $\mathrm{D}_{2} \mathrm{O}$ : (a) ${ }^{1} \mathrm{H}$ NMR spectra at $300 \mathrm{MHz}$ and (b) ${ }^{13} \mathrm{C}$ NMR spectra at $125 \mathrm{MHz}$. 
Section B:

Further Information on Samples From the Bicontinuous Microemulsion Phase of the $M\left(D^{\prime} E_{7} O H\right) M / D 4 /$ Water System

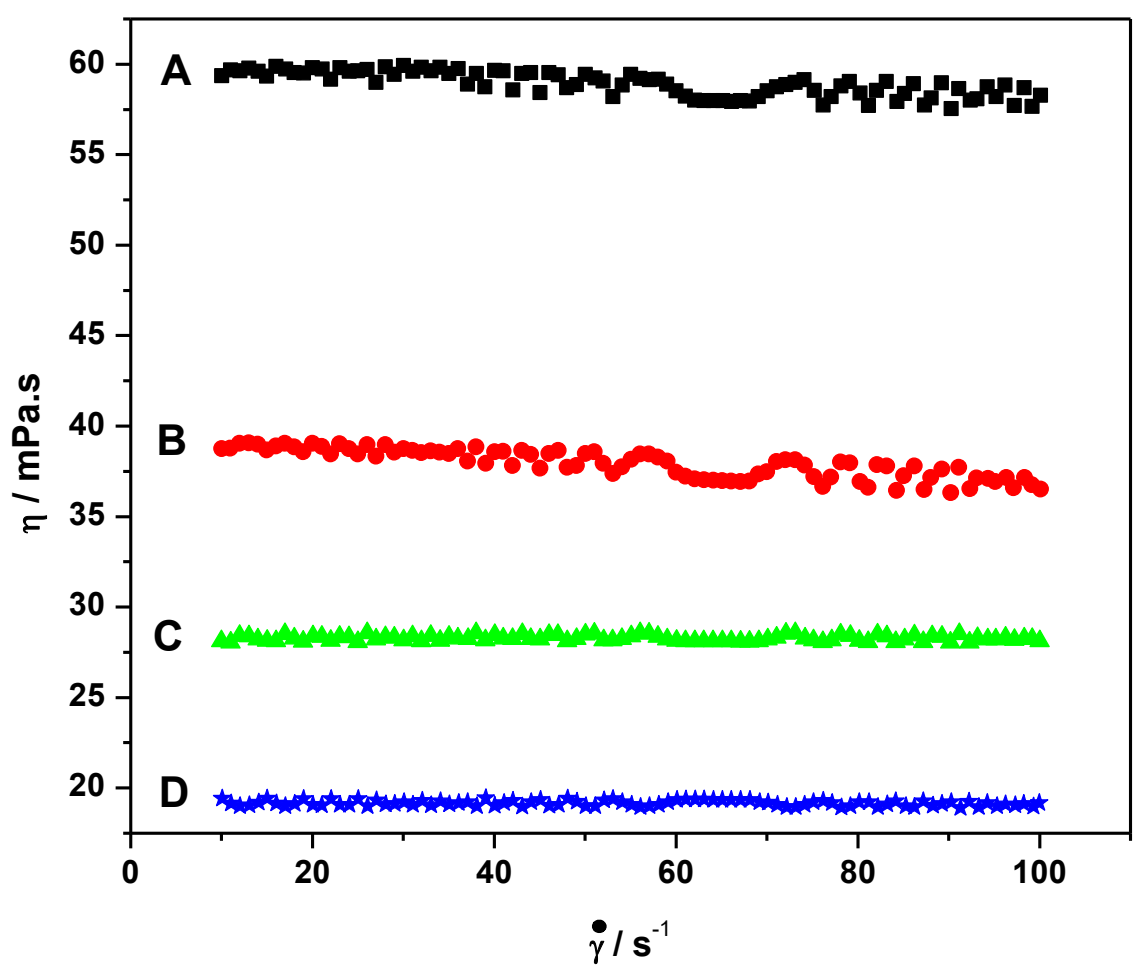

Figure S3. Flow curves of the system composed of $\mathrm{M}\left(\mathrm{D}^{\prime} \mathrm{E} 7 \mathrm{OH}\right) \mathrm{M} / \mathrm{D} 4 /$ water to obtain the viscosity as a function of the surfactant concentration at $25^{\circ} \mathrm{C}$.

Table S1. Composition and viscosity of samples of bicontinuous microemulsions (L3) constituted by $\mathrm{M}\left(\mathrm{D}^{\prime} \mathrm{E}_{7} \mathrm{OH}\right) \mathrm{M} / \mathrm{D} 4 /$ water at $25^{\circ} \mathrm{C}$.

\begin{tabular}{|c|c|c|c|c|}
\hline Sample & $\begin{array}{c}\text { Wt\% } \\
\text { water }\end{array}$ & $\begin{array}{c}\text { Wt\% } \\
\text { D4 }\end{array}$ & $\begin{array}{c}\mathbf{W t} \% \\
\mathbf{M}\left(\mathbf{D}^{\prime} \mathbf{E}_{7} \mathbf{O H}\right) \mathbf{M}\end{array}$ & $\begin{array}{c}\boldsymbol{\eta} \\
(\mathbf{m P a} . \mathbf{s})\end{array}$ \\
\hline A & 8.77 & 9.14 & 82.09 & 58.4 \\
\hline B & 7.08 & 27.96 & 64.96 & 36.4 \\
\hline C & 5.30 & 47.13 & 47.56 & 38.6 \\
\hline D & 3.83 & 62.00 & 34.17 & 19.2 \\
\hline
\end{tabular}




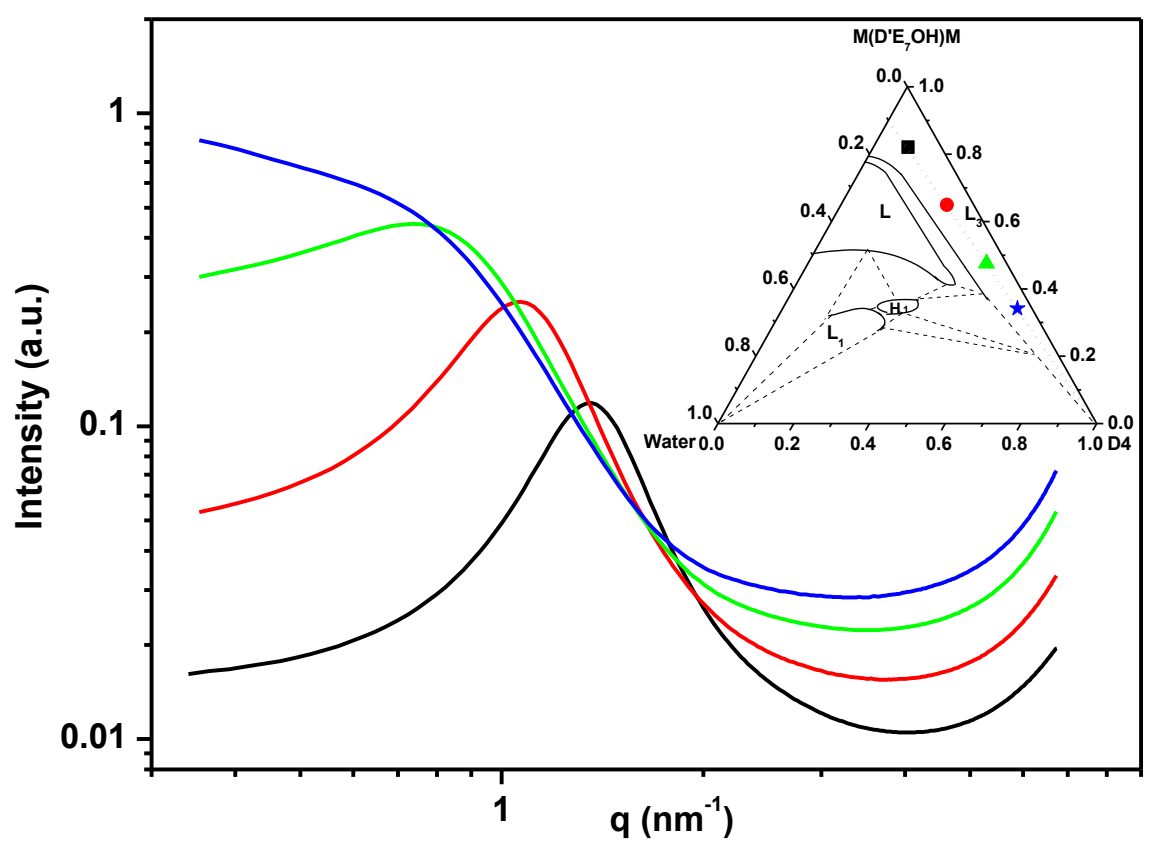

Figure S4. SAXS curves for bicontinuous microemulsion samples selected for viscosity experiments. $\mathrm{M}\left(\mathrm{D}^{\prime} \mathrm{E}_{7} \mathrm{OH}\right) \mathrm{M} / \mathrm{D} 4$ (cyclic oil)/Water system along a surfactant concentration line, as shown in the phase diagram (insert).

Table S2.Indication of the samples referring to the water dilution line for the system composed of $\mathrm{M}\left(\mathrm{D}^{\prime} \mathrm{E} 7 \mathrm{OH}\right) \mathrm{M} / \mathrm{D} 4 /$ water at $25^{\circ} \mathrm{C}$ shown in Figure 3.

\begin{tabular}{|c|c|c|c|}
\hline Sample & Wt\% water & Wt\% D4 & Wt\% $\mathbf{M}\left(\mathbf{D}^{\prime} \mathbf{E}_{7} \mathbf{O H}\right) \mathbf{M}$ \\
\hline A & 0.00 & 49.87 & 50.13 \\
\hline B & 1.05 & 49.34 & 49.61 \\
\hline C & 2.11 & 48.81 & 49.07 \\
\hline D & 3.22 & 48.26 & 48.52 \\
\hline E & 4.36 & 47.69 & 47.95 \\
\hline F & 5.59 & 47.08 & 47.33 \\
\hline G & 6.87 & 46.44 & 46.69 \\
\hline H & 8.22 & 45.77 & 46.01 \\
\hline I & 11.09 & 44.34 & 44.58 \\
\hline
\end{tabular}




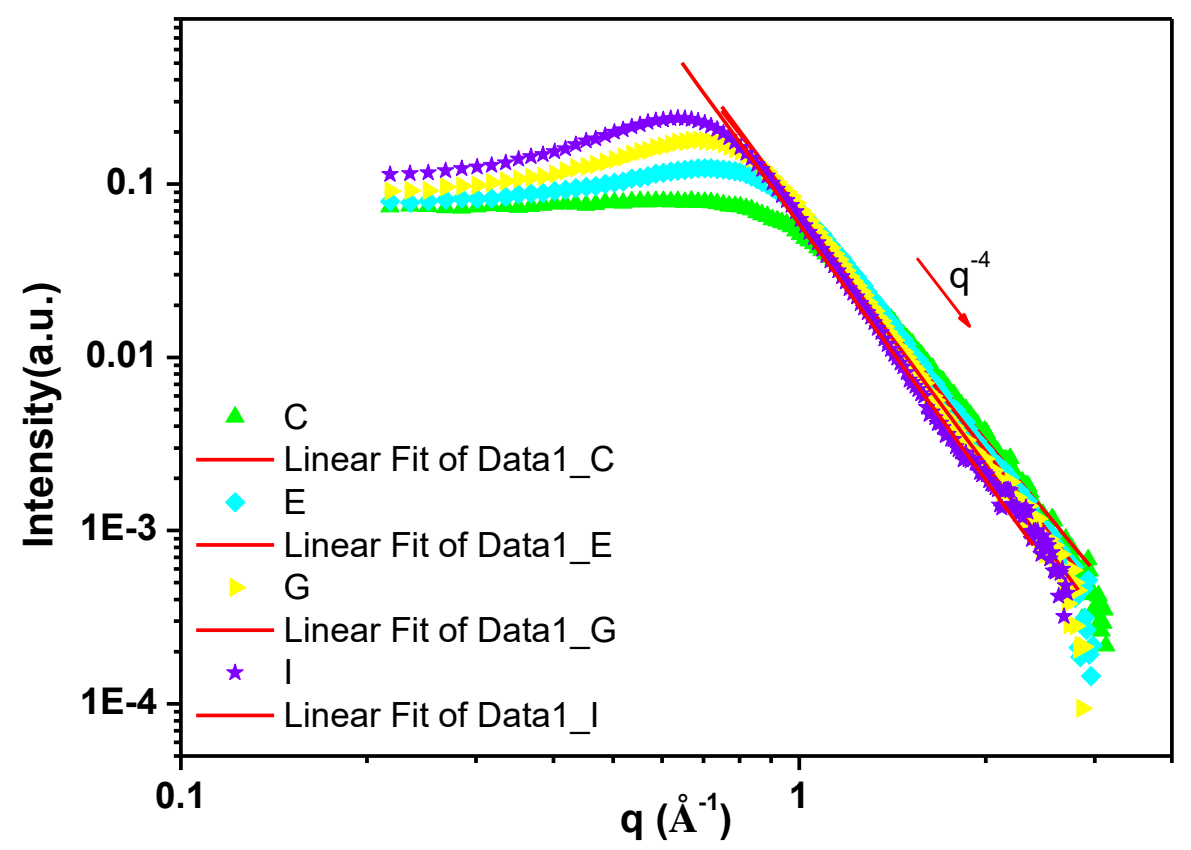

Figure S5. Angular dependence of approximately $\mathrm{q}^{-4}$ at high values of $\mathrm{q}$ for the samples mentioned above (samples C, E, G and I).

Table S3. Results obtained from fitting of the SAXS curves to the Teubner-Strey model for the system composed of $\mathrm{M}\left(\mathrm{D}^{\prime} \mathrm{E} 7 \mathrm{OH}\right) \mathrm{M} / \mathrm{D} 4 /$ water at $25^{\circ} \mathrm{C}$. Symbols: $\xi$ represents the correlation length; $d$ represents the domain periodicity; $\chi^{2}$ represents the relative accuracy of each adjustment performed.

\begin{tabular}{|c|c|c|c|c|}
\hline Sample & $\begin{array}{c}\text { Wt\% } \\
\text { hydrophilic phase }\end{array}$ & $\begin{array}{c}\boldsymbol{\xi} \\
(\mathbf{\AA})\end{array}$ & $\begin{array}{c}\mathbf{d} \\
(\mathbf{\AA})\end{array}$ & $\chi^{2}$ \\
\hline A & 28.7 & 13.0 & 83.5 & 0.060 \\
\hline B & 29.5 & 16.2 & 81.0 & 0.062 \\
\hline C & 30.2 & 20.6 & 77.9 & 0.064 \\
\hline D & 31.0 & 25.5 & 78.2 & 0.066 \\
\hline E & 31.8 & 28.5 & 79.0 & 0.066 \\
\hline F & 32.7 & 32.0 & 81.0 & 0.067 \\
\hline G & 33.6 & 35.1 & 83.8 & 0.067 \\
\hline H & 34.6 & 37.3 & 87.1 & 0.068 \\
\hline I & 35.6 & 39.3 & 91.1 & 0.068 \\
\hline
\end{tabular}




\section{SECTION C:}

SAXS Curves Showing the Total Transformation of the Bicontinuous

Microemulsion Phase at $25{ }^{\circ} \mathrm{C}$ Into a Lamellar Phase at $5{ }^{\circ} \mathrm{C}$
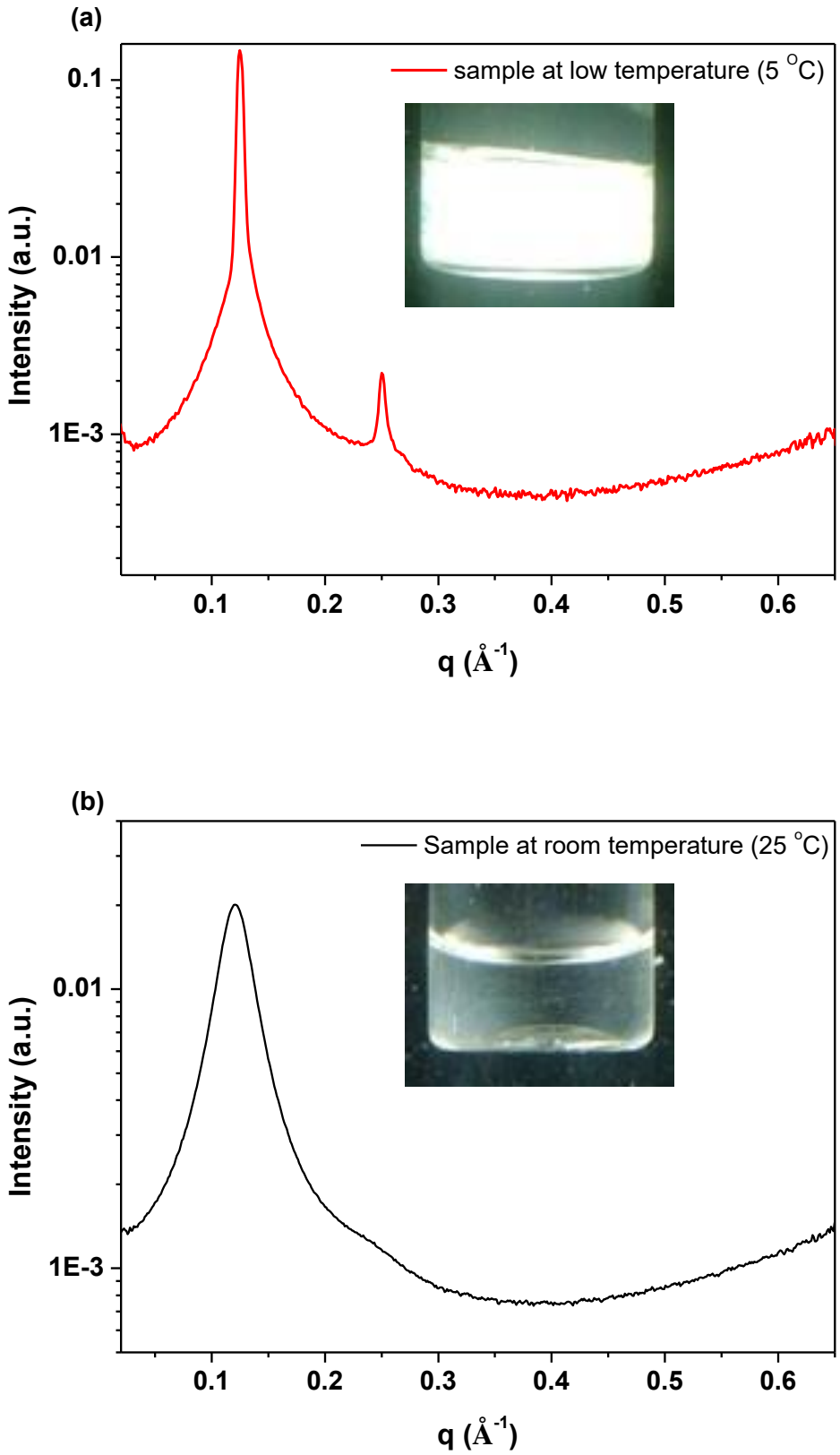

Figure S6. SAXS spectra of the sample whose composition is $18.6 \mathrm{wt} \%$ water, $5.7 \mathrm{wt} \%$ $\mathrm{D}_{4}$ and $\left.75.7 \% \mathrm{wt} \mathrm{M}\left(\mathrm{D}^{\prime} \mathrm{E}_{7} \mathrm{OH}\right) \mathrm{M}\right)$ and their respective images between crossed-polarizers at (a) $5^{\circ} \mathrm{C}$ and (b) $25^{\circ} \mathrm{C}$. 


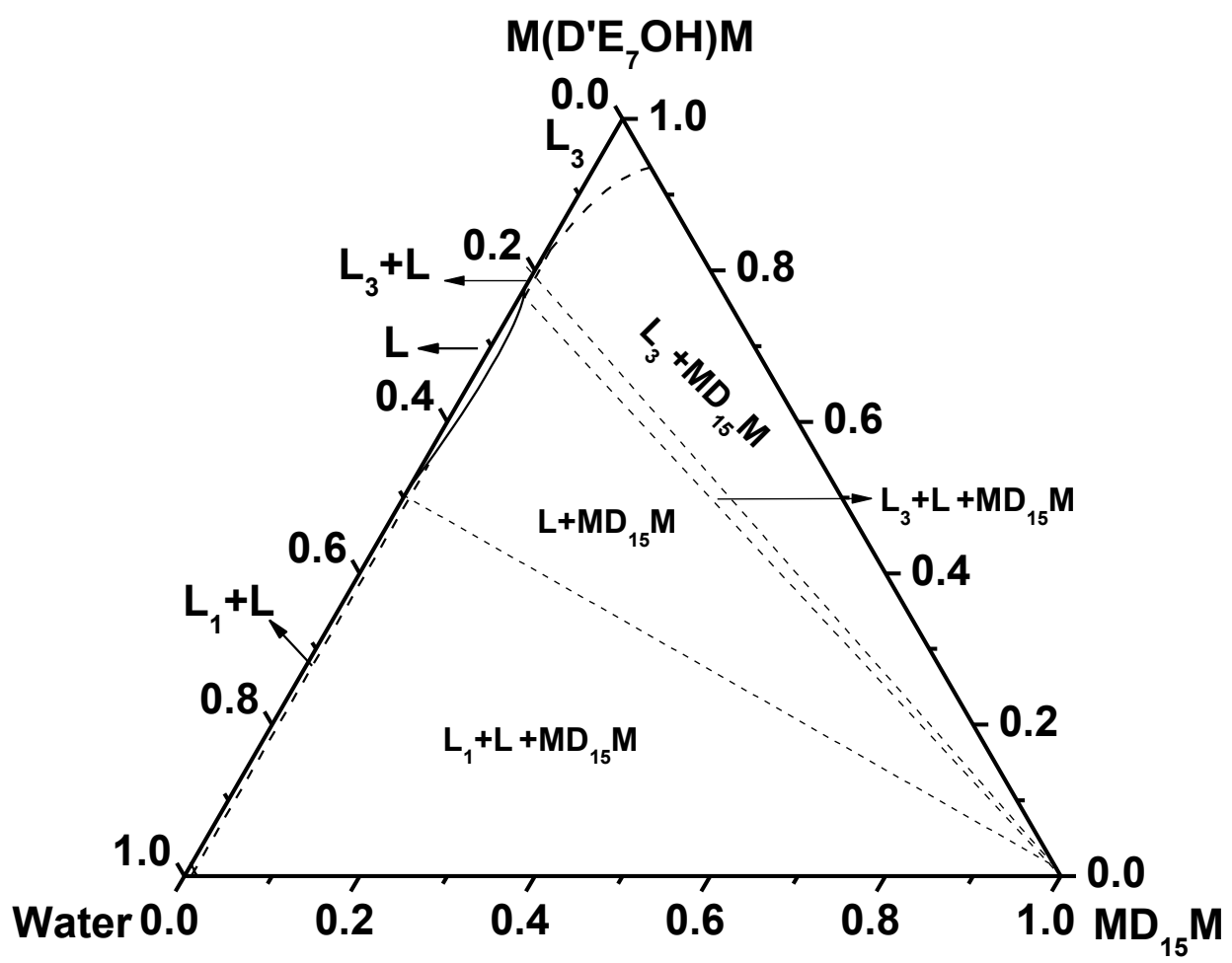

Figure S7. Phase diagram for the system formed by $M\left(D^{\prime} E_{7} O H\right) M / M D_{15} M / W a t e r$ at $25^{\circ} \mathrm{C}$. L (lamellar phase), $\mathrm{L}_{1}$ (water-in-oil microemulsion), $\mathrm{L}_{3}$ (bicontinuous microemulsion), two-phase region $\left(\mathrm{L}_{3}+\mathrm{MD}_{15} \mathrm{M}\right.$ and $\left.\mathrm{L}+\mathrm{MD}{ }_{15} \mathrm{M}\right)$ and three-phase region $\left(\mathrm{L}_{3}+\mathrm{L}+\mathrm{MD}_{15} \mathrm{M}\right.$ and $\left.\mathrm{L}_{1}+\mathrm{L}+\mathrm{MD} 15 \mathrm{M}\right)$. 

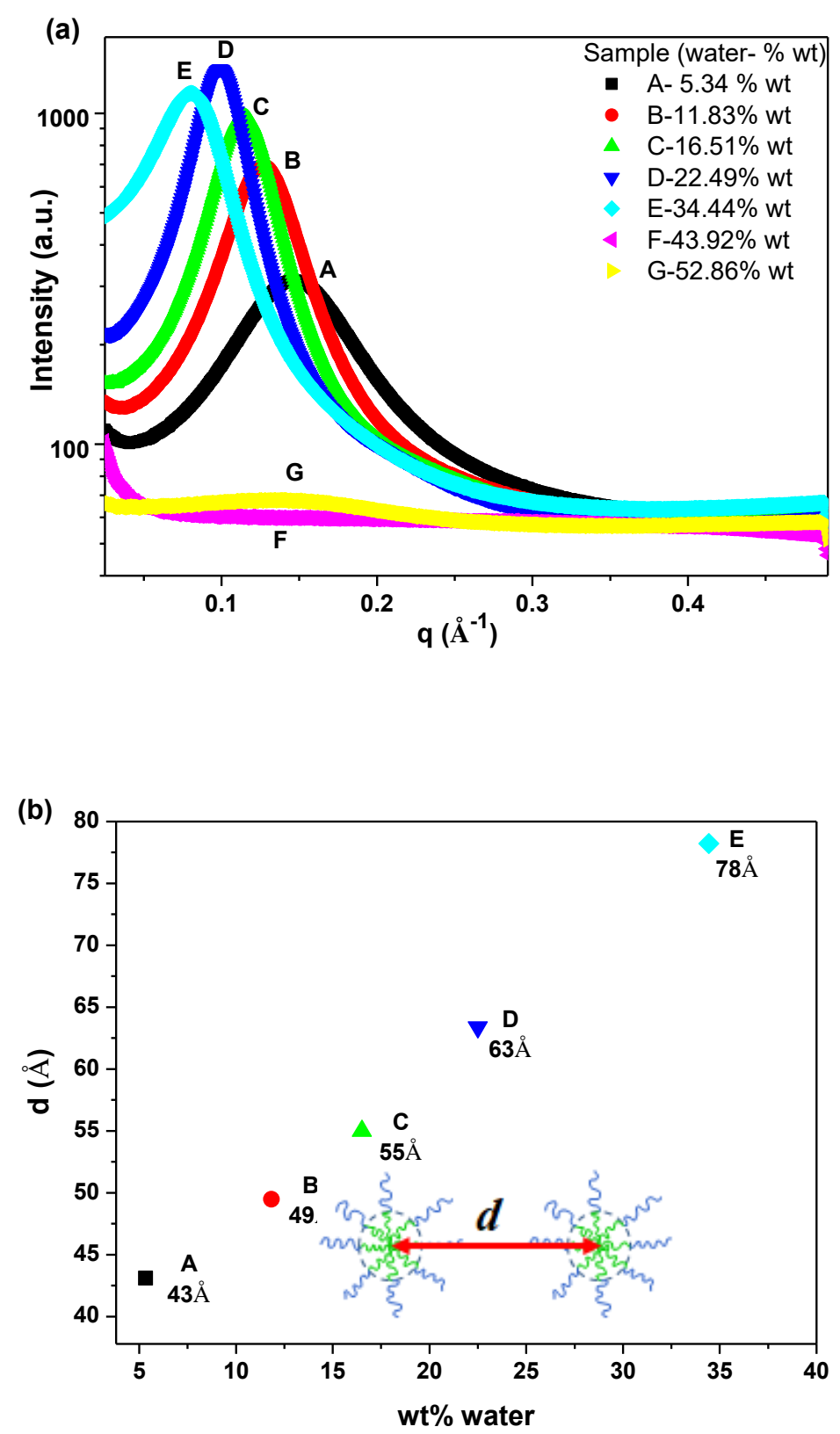

Figure S8. (a) SAXS curves of the system composed of $\mathrm{M}\left(\mathrm{D}^{\prime} \mathrm{E}_{7} \mathrm{OH}\right) \mathrm{M} / \mathrm{MD}_{15} \mathrm{M} / \mathrm{W}$ ater at $25{ }^{\circ}$ C. Samples with variation of the amount of water identified in Figure C1, bottom phase representing an oil-in-water microemulsion. (b) Increase in the distance of droplets of the microemulsion phase formed with different $\mathrm{M}\left(\mathrm{D}^{\prime} \mathrm{E}_{7} \mathrm{OH}\right) \mathrm{M}: \mathrm{MD}_{15} \mathrm{M}$ mass ratio, as a function of the water content. 


\section{SECTION E:}

Phase Diagram for the Ternary System $\mathrm{MD}_{18}\left(\mathrm{D}_{3}{ }_{3} \mathrm{E}_{18} \mathrm{OAC}\right) \mathrm{M} / \mathrm{MD}_{15} \mathrm{M} /$ Water

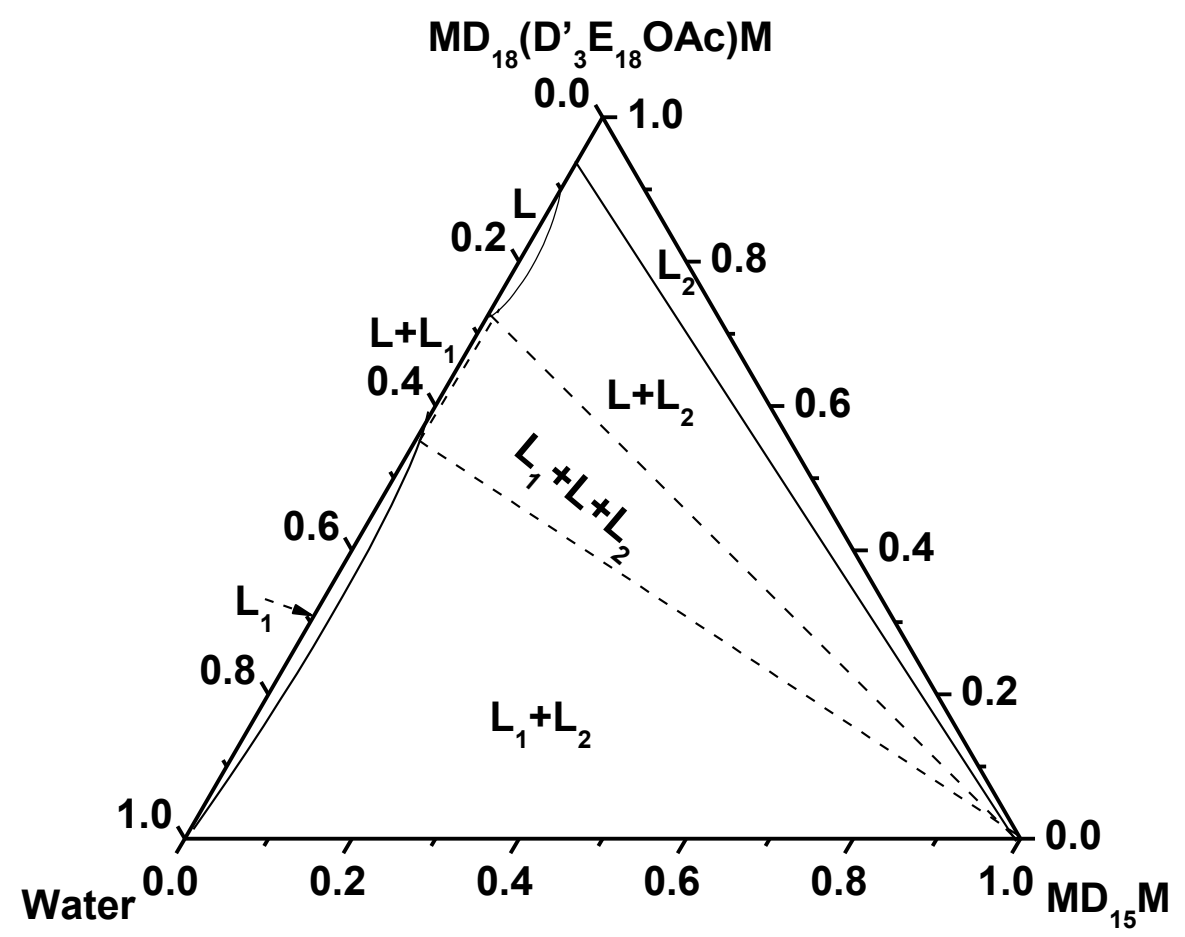

Figure S9. Phase diagram for the ternary system $\mathrm{MD}_{18}\left(\mathrm{D}_{3}{ }_{3} \mathrm{E}_{18} \mathrm{OAc}\right) \mathrm{M} / \mathrm{MD}{ }_{15} \mathrm{M} /$ water, at $25{ }^{\circ}$ C.L1 (oil-in-water microemulsion); L2 (water-in-oil microemulsion); L (lamellar phase). 